\title{
MANAJEMEN PRODUKSI DAN PEMELIHARAAN KEBUN KELAPA SAWIT RAKYAT
}

\author{
Latifa Siswati ${ }^{1}$ Resolinda Harly ${ }^{2}$, Afrijon $^{3}$ \\ 1).Universitas Lancang Kuning Pekanbaru \\ 2)Sekolah Tinggi Pertanian Haji Agus Salim Bukittinggi \\ 3).Akademi Pembangunan Pertanian (APPERTA) Sumbar \\ Email: latifasiswati123@gmail.com,resolindaharly@gmail.com
}

\begin{abstract}
ABSTRAK
Penelitian ini dilakukan bertujuan untuk mengetahui manajemen pemeliharaan kebun sawit terutama pemupukan dan produksi yang dihasilkan pada perkebunan sawit rakyat di kecamatan Lubuk Basung. Metode survey dan wawancara dilaksanakan pada penelitian ini, dengan 38 petani responden. Analisis data secara deskriptif dalam bentuk tabel dan grafik disajikan pada hasil penelitian. Hasil penelitian diperoleh $92 \%$ kondisi tanaman kebun kelapa sawit rakyat pada masa menghasilkan dan sebanyak $8 \%$ tanaman kebun kelapa sawit rakyat berada pada tanaman belum menghasilkan. Dari pelaksanaan pemupukan yang dilakukan petani responden $42,10 \%$ tidak melakukan pemupukan , 31,58\% melakukan pemupukan dengan frekuensi satu kali setahun sedangkan pelaksanaan pemupukan dengan aplikasi dua kali setahun dilakukan oleh $26,32 \%$ responden. Berhubungan dengan produksi yang dihasilkan petani responden dibandingkan dengan produksi pusat penelitian kelapa sawit, produksi kelapa sawit rakyat masih rendah dibawah produksi kelapa sawit pusat penelitian kelapa sawit. Kondisi ini dapat diperkuat yang disebabkan oleh asal bibit tanaman yang digunakan oleh petani responden tidak memiliki keunggulan yang dibuktikan dengan sertifikat/label. Hasil penelitian menunjukkan $71,05 \%$ sumber bibit tanaman diperoleh dari masyarakat sekitar, $10,53 \%$ berasal dari luar daerah dan $7,89 \%$ dari perusahaan perkebunan.

Kata kunci : manajemen pemupukkan, produksi, sumber bibit tanaman
\end{abstract}

\section{PENDAHULUAN}

Kelapa sawit (Elaeis guineensis Jacq.)merupakan tanaman perkebunan penting penghasil; minyak makan,minyak industry, maupun bahan bakar nabati (biodiesel). Sebagai penghasil minyak sawit Indonesia berada pada urutan pertama dunia diikuti oleh Malaysia. Kelapa sawit merupakan salah satu komoditi perkebunan yang perkembangannya sangat pesat dibandingkan dengan komoditi lain dalam perkebunan. Perkebunan kelapa sawit sangat banyak melibatkan masyarakat sebagai pelaku usahatani dan juga ikut serta pada peningkatan ekonomi kerakyatan. Kondisi luas kebun kelapa sawit tahun 2015 menurut data statistik sebesar 10,75 Ha, dari luasan yang ada 52,10\% dikuasai oleh perkebunan 
besar swasta dan $41,12 \%$ dikuasai oleh perkebunan rakyat hanya $6,78 \%$ yang dikelola oleh negara.

Permasalahan yang terjadi adalah produksi kebun kelapa sawit pada perkebunan rakyat jauh lebih rendah dibandingkan dengan perkebunan yang dikelola oleh perusahaan maupun perkebunan inti rakyat binaan dari perusahaan. Banyak faktor yang menyebabkan produksi rendah seperti penggunaan bibit,teknik budidaya dan sumber daya manusia yang rendah.Pemupukan merupakan salah satu tindakan perawatan yang harus dilakukan oleh petani untuk meningkatkan pertumbuhan dan produktivitas tanaman. Pemupukan bertujuan untuk menambahkan ketersediaan unsur hara di dalam tanah sehingga produktivitas meningkat. Dinas Perkebunan Propinsi Riau (2008), pada perkebunan rakyat pemupukan dilakukan apabila tanaman telah menghasilkan dan juga kalau dana mencukupi untuk pembelian pupuk. Pada tanaman yang sudah menghasilkan seringkali terjadi pemupukan yang kurang memadai sehingga tidak diperoleh hasil TBS yang optimal dibandingkan dengan yang dihasilkan oleh perkebunan besar .

Manajemen bersama tiga faktor produksi seperti tanah, modal, dan tenaga kerja harus saling mendukung untuk memberikan hasil usaha yang memuaskan. Herujito dan Yayat M,2001 menjelaskan manajemen perkebunan adalah ilmu yang mengatur dan mengelola pelaksanaan proses/kegiatan-kegiatan dalam perkebunan untuk mencapai keuntungan yang diharapkan secara efektif dan efisien.Pengelolaan yang baik menurut aturan akan memberikan hasil yang baik pula. Penelitian ini dilakukan bertujuan untuk mengetahui pengetahuan petani tentang manajemen pemeliharaan (penggunaan bibit dan pemupukan) yang dilaksanakan pada kebun kelapa sawit.

\section{METODE PENELITIAN}

Penelitian ini dilakukan di kecamatan lubuk basung kabupaten agam dan kecamatan lubuk tarok kabupaten sijunjung. Penelitian dilaksanakan pada bulan April sampai juli 2017. Penetapan lokasi dilakukan secara purposive yaitu daerah yang kebun rakyatnya banyak dan memiliki ternak kerbau sebagai pengguna limbah kebun sawit. Penelitian dilakukan dengan metoda survey dengan mengacu kepada kuesioner yang sudah dipersiapkan. Pengambilan sampel dilakukan secara sengaja kepada petani pekebun dan yang memiliki ternak kerbau. 
Data yang dikumpulkan meliputi data primer dan data sekunder. Data primer diperoleh dari wawancara langsung dengan petani meliputi karakteristik ( nama ,umur, jumlah tanggungan keluarga, pengalaman berkebun, luasan lahan yang diusahakan), pengetahuan petani terhadap bibit (sumber bibit), pemupukan (cara, kuantitas pupuk dan waktu pemupukan). Sedangkan data sekunder diperoleh dari kantor kabupaten dan instansi terkait.

Analisis data dilakukan secara deskriptif dengan cara membuat tabulasi distribusi responden dan setiap variable yang diteliti yang ditampilkan dalam bentuk table dan grafik.

\section{HASIL DAN PEMBAHASAN}

Berdasarkan informasi dari petani responden sebagian besar petani memperoleh bibit tanaman dari masyarakat sekitar 71,05\%, bibit sendiri dan luar daerah sama 10,53\%, sebanyak 7,89\% petani memperoleh dari perusahaan perkebunan. Berbagai asal sumber bibit tanaman diperoleh oleh petani, akan tetapi perolehan bibit tanaman tersebut tidak memiliki informasi yang akurat tentang bibit tanaman seperti bukti sertifikat/label, sehingga bibit tanaman tidak dapat dipertanggunjawabkan kemurniaan atau keaslian sebagai bibit tanaman yang berkualitas. Petani hanya mengetahui informasi dari penjual akan kualititas bibit yang mereka miliki. Alasan diperoleh dari petani membeli bibit tanaman dari masyarakat sekitar dikarenakan harga yang murah.Tabel 1. Memperlihatkan asal bibit tanaman yang dimiliki petani

Tabel 1. Sumber Bibit Tanaman yang digunakan Responden

\begin{tabular}{lllll}
\hline No & \multicolumn{1}{c}{$\begin{array}{c}\text { Asal Bibit } \\
\text { Tanaman }\end{array}$} & & Jumlah Responden & Persentase (\%) \\
\hline 1 & Bibit sendiri & 4 & 10,53 \\
2 & PT & 3 & 7,89 \\
3 & Masyarakat sekitar & 27 & 71,05 \\
4 & Luar daerah & 4 & 10,53 \\
\hline & Jumlah & 38 & 100 \\
\hline
\end{tabular}

Kurangnya pengetahuan petani tentang bibit tanaman yang baik akan berakibat pada produksi yang dihasilkan rendah sehingga akan berimbas pada penghasilan petani. . Bibit yang baik menjadi penentu produksi yang dihasilkan. Tiga faktor yang mempengaruhi produktivitas kelapa sawit adalah pemilihan bibit

97 Manajemen Produksi Dan Pemeliharaan Kebun Kelapa Sawit Rakyat 
unggul,pemeliharaan tanaman dan teknologi panen ( Pahan,2010). Selanjutnya menurut Lubis dan Widanarno (2011) kesalahan dalam penentuan bibit berakibat hingga replanting (25-30 tahun) oleh karena itu bibit yang baik harus diperoleh dari kecambah kelapa sawit yang digunakan berasal dari produsen yang diakui swasta dan pemerintah (sertifikat diakui dan legal).

\section{Pemupukan}

Salah satu kegiatan pemeliharaan tanaman kelapa sawit adalah pemupukan. Pemupukan berpengaruh besar terhadap pertumbuhan dan produksi tanaman.Pemupukan bertujuan untuk menambahkan ketersediaan unsur hara di dalam tanah, kekurangan unsur hara tanaman dapat diketahui dari gejala-gejala yang tampak pada tanaman.Hasil penelitian memberikan informasi bahwa jenis pupuk yang diberikan petani adalah: Ponska, Urea, ZA, SP 36 dan NPK. Unsur hara utama/penting pada tanaman kelapa sawit meliputi $\mathrm{N}, \mathrm{P}, \mathrm{K}, \mathrm{Mg}, \mathrm{Cu}$ dan $\mathrm{B}$, setiap unsur hara tersebut harus cukup tersedia dalam tanah, apabila ketersediaannya tidak mencukupi tanaman akan mengalami gejala defisiensi yang mengakibatkan proses metabolism tanaman akan terganggu yang mengakibatkan produksi tidak optimal (Mangoensoekarjo,2007). Pemberian pupuk yang dilakukan petani secara umum belum sesuai baik secara jenis, kuantitas, cara dan kualitas. Frekuensi pemberian pupuk yang dilakukan petani seperti pada Tabel 2.

Tabel 2. Frekuensi pemberian pupuk oleh responden (/tahun)

\begin{tabular}{|c|c|c|c|}
\hline No & $\begin{array}{c}\text { Frekuensi } \\
\text { pemupukan/tahun }\end{array}$ & Jumlah Orang) & Persentase (\%) \\
\hline 1 & $1 \mathrm{x}$ & 12 & 31,58 \\
\hline 2 & $2 x$ & 10 & 26,32 \\
\hline \multirow[t]{2}{*}{3} & Tidak diberi/kadang2 & 16 & 42,10 \\
\hline & Jumlah & 38 & 100 \\
\hline
\end{tabular}

Berdasarkan hasil penelitian jumlah petani yang tidak melakukan atau kadang-kadang melakukan pemupukan berada pada persentase yang tinggi yaitu 42,10\%, diikuti dengan melakukan pemupukan satu kali sebesar 331,58\% dan dua kali pemupukan sebesar 26,32 \%. Pahan (2008) memberikan rekomendasi pemupukan mengacu pada konsep 5T yaitu: tepat jenis, tepat dosis,tepat cara,tepat waktu dan tepat kualitas. Hasil wawancara dengan petani responden ,kegiatan pemupukan dilakukan apabila keadaan keuangan mencukupi untuk pembelian 
pupuk dan jumlah yang diberikan belum sesuai menurut umur tanaman dan cara pemupukan yang baik.

\section{Produksi}

Penanaman kelapa sawit ditujukan untuk menghasilkan produksi yang optimal yang dapat dihasilkan oleh tanaman sawit.Produksi kelapa sawit sangat ditentukan oleh faktor teknik budidaya yang baik dan benar.Jika dalam teknik budidayanya sudah benar maka hasil produksi akan optimal dan jika sebaliknya maka produksi akan kurang memuaskan. Komposisi tanaman sawit petani berada pada $92 \%$ tanaman menghasilkan dan hanya $8 \%$ tanaman berada pada tanaman belum menghasilkan.

Tabel 3.Perbandingan Produksi Kebun Kelapa Sawit Rakyat dan PPKS

\begin{tabular}{llll}
\hline No & $\begin{array}{c}\text { Umur Tanaman } \\
\text { (th) }\end{array}$ & \multicolumn{1}{c}{$\begin{array}{c}\text { Produksi kebun sawit } \\
\text { petani } \\
(\mathrm{Kg} / \mathrm{Ha} / \mathrm{Th})\end{array}$} & $\begin{array}{c}\text { Produksi kebun sawit } \\
\text { PPKS }(\mathrm{Kg} / \mathrm{Ha} / \mathrm{Th})\end{array}$ \\
\hline 1 & 4 & 9000 & 13500 \\
2 & 5 & - & 16000 \\
3 & 6 & 12600 & 18500 \\
4 & 7 & - & 23000 \\
5 & 8 & - & 25500 \\
6 & 12 & 18000 & - \\
\hline
\end{tabular}

Sumber : Hasil Penelitian dan PPKS

Keaslian bibit yang digunakan pada kebun kelapa sawit merupakan salah satu penentu produktivitas (Purwantoro,2008). Hasil penelitian Juliza Hidayati, Sukardi, Ani Suryani, Anas Miftah Fauzi, Sugiharto (2016), menyatakan faktorfaktor yang berdampak besar pada peningkatan produktivitas perkebunan sawit berturut-turut adalah kesehatan tanaman,penyisipan bibit, jenis pupuk, prosedur kerja,pengendalian gulma ,pengendalian hama penyakit, teknologi pemupukan, dan pemupukan bibit.

Gambar1. lebih jelas untuk melihat perbandingan antara produksi kebun kelapa sawit rakyat dengan produksi hasil kebun kelapa sawit pada Pusat Pengembangan Kebun Sawit Medan (PPKS). 


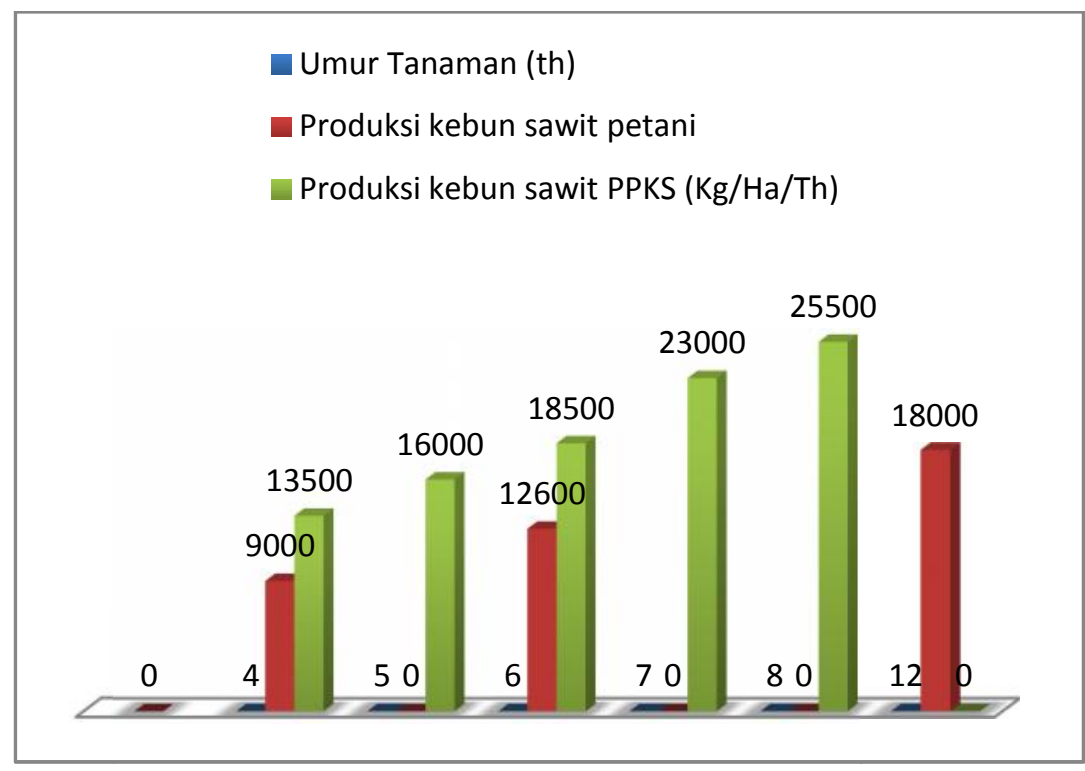

Gambar 1. Produkstivitas Kebun Kelapa Sawit

\section{KESIMPULAN}

Dari hasil penelitian yang dilakukan diperoleh kesimpulan, manajemen kebun kelapa sawit rakyat terutama pemupukan belum dilaksanakan menurut anjuran dan belum memenuhi kebutuhan tanaman. Produksi kebun kelapa sawit rakyat dibandingkan dengan produksi kelapa sawit pada pusat pengembangan kelapa sawit masih rendah, hal ini sehubungan dengan asal bibit tanaman yang tidak jelas atau tidak punya lebel sertifikat unggul.

\section{DAFTAR PUSTAKA}

Badan Pusat Statistik .2015. Statistik Kelapa Sawit Indonesia. Badan Pusat Statistik. Jakarta

Fauzi, Widyastuti, Sastyawibawa dan Hartono. 2005. Kelapa Sawit, Budidaya Pemanfaatan Hasil \& Limbah, Analisis Usaha \& Pemasaran. Penebar Swadaya. Jakarta. 168 hal.

Juliza Hidayati, Sukardi, Ani Suryani, Anas Miftah Fauzi, Sugiharto (2016). Identifikasi Revitalisasi Perkebunan Kelapa Sawit Di Sumatera Utara. Ju rnal Teknologi Industri Pertanian 26 (3):255-265 (2016)

Lubis, R. E dan A. Widanarko. 2011. Buku Pintar Kelapa Sawit. Agromedia Pustaka. Jakarta.

Mangoensoekarjo, S. 2007. Manajemen Agrobisnis Kelapa Sawit. Gajah Mada University Press. Yogyakarta. 
Pahan, I.2010. Panduan lengkap Kelapa sawit.Managemen Agribisnis dari hulu hingga hilir. Penebar Swadaya. Jakarta.

-------, 2008.Panduan Lengkap Kelapa Sawit. Penebar Swadaya. Jakarta

Purwantoro RN. 2008. Sekilas pandang industry sawit. Majalah Manajemen UsahawanIndonesia LM FEU. 04:1-18

Juliza Hidayati, Sukardi, Ani Suryani, Anas Miftah Fauzi, Sugiharto (2016). Identifikasi Revitalisasi Perkebunan Kelapa Sawit Di Sumatera Utara. Ju rnal Teknologi Industri Pertanian 26 (3):255-265 (2016)

Santoso. Pelaksanaan Teknik Budidaya Kelapa Sawit (Elaeis Guineensis Jacq) Swadaya Masyarakat Di Lahan Pasang Surut Kecamatan Bangko Pusako Kabupaten Rokan Hilir. Http://Download.Portalgaruda.Org/Article.Php?Article=186821\&Val=644 8\&Title=Pelaksanaan $\% 20$ teknik $\% 20 \mathrm{~b}$ 